\title{
Factors Motivating the Public to Participate in Crowdsourcing of Crime Information
}

\author{
Badariah Solemon ${ }^{1 *}$, Wan Muhammad Luqman Wan Abu Bakar ${ }^{2}$ \\ ${ }^{1}$ College of Computer Science and Information Technology, Universiti Tenaga Nasional \\ ${ }^{2}$ College of Graduate Studies, Universiti Tenaga Nasional \\ *Corresponding author E-mail: badariah@uniten.edu.my
}

\begin{abstract}
This paper presents the results of an exploratory study conducted to identify the factors that influence people and communities to participate in crowdsourcing approach of crime information. The study uses as survey, self-administered questionnaires distributed to the crowd in the public areas in Selangor and Wilayah Persekutuan, Malaysia as well as through an online survey website. Analysis performed to more than half of 139 valid responses of the survey reveals that the respondents participated in crowdsourced crime reporting and sharing using recent technologies such as mobile application mainly to help reduce the crime rate (nature of problem factor); to contribute to the betterment of mankind and they like the idea of contributing to something of value to the world (altruism factor); to exchange ideas or knowledge on crime information with the crowdsourcing community and to obtain crime related information (learning factor); to share crime related information to others (interest in topic); and to alert others so they can be more cautious (reciprocity factor). Findings from this survey have guided a research work to develop a prototype of mobile application to demonstrate how the application can support neighborhood crime watch activity by enabling community members to share crime incidents information.
\end{abstract}

Keywords: motivation, factor; crowdsourcing; crime information.

\section{Introduction}

Nowadays, one of the major concerns of our society remain facing is high crime levels, even in nations with a high standard of living [1]. In the recent mid-year 2017 crime index produced by Numbeo, numbers have shown that even developed countries such as Sweden, United States, and Norway are ranked among the top 50 while Malaysia is ranked at a jaw-dropping top $17^{\text {th }}$ of the compiled data from over 110 countries in the world. Two victimization theories known as the "lifestyle exposure theory" [2] and the "routine activity theory" [3] theorize that a crime happens when there are three co-existing components: motivated criminal, vulnerable victim and a supporting environment.

With growing crime levels including those reported in Numbeo, various research work have investigated how community policing activities can be supported and outlined basic design principles for technologies intended for crime prevention [4]. Some of these researchers together with law enforcement authorities have focused on crime prevention technologies to help people lower the risk of victimization. One of these technologies is crime mapping, which enables the citizens to share crime-related information on a map and the locations of previous incidents [5]. Success of crime mapping platforms deployed by police force, has lead to emergence of numerous commercial crime prevention information systems such as CrimeReports [6] and Crimemapping [7] that provide the likelihood for the users to obtain insights into the official criminal statistics. Within the area of data aggregation and analysis, some research have provided the possibility for automatic identification of crime hotspots [8], and prediction of potential future incidents, a practice commonly known as predictive policing [9]. Moreover, crowdsourcing platforms were created to enable individuals to actively participate in the sharing of private crime-related experiences with other users or the authorities. Such platforms include WikiCrimes [10] and CrimePush [11].

Apart from crowdsourcing platforms based on the principles of crime mapping, crime prevention solutions for increasing individual safety have been investigated too. These crime prevention solutions include wearable computers to reduce fear among elderly [12] or to increase children's through parental surveillance [13] and hand-held devices to unconsciously records and shares the location of an individual in large cities at night [14]. Researchers have also investigated the possibility for smart phones utilization for crime prevention such as a mobile application proposed by Blom, Viswanathan, Spasojevic, Go, Acharya and Ahonius [15] to allow individuals to tag risky urban regions on a virtual map.

In our research presented in [16], six mobile applications that can be used to report and share crime information in Malaysia were reviewed including 1) MyDistress 2) CrimeWatch Mobile 3) Malaysia Crime 4) Community Alert 5) Community Against Crime and 6) Enforce Crime Map. Using Enforce Crime Map, a user may view crime occurred, find the location of the crime and tag the media (video or picture) of the crime with the geographical location information for mapping purposes. CrimeWatch Mobile mobile application enable its users to view crime information within one mile radius of the users' current locations, which were submitted by joining agencies under the CrimeWatch Network. Соттиnity Against Crime application enables users to receive crime information through email as well as short messaging service (SMS) whenever there is a new crime reported. Malaysia Crime is an application locally developed for Malaysian citizen by Apptivity Lab to enables the crowd to report a crime through a web application and to view the reported crime either via the web application or the mobile application. Community Alert requires users to pro- 
vide their particular such as name, phone number and identity card number to enable its users to submit crime reports but also request emergency assistance in the case of flood and fire within Malaysia and Singapore. Operations of Community Alert works and MyDistress are generally very similar except that any crime reported through this application will activate an alert call the police force Malaysian Royal Police Department, also known as Polis Di Raja Malaysia (PDRM) and enable users to locate the nearest police station within their current location. Unfortunately, the application can only be used within the Selangor state only.

Motivated to reduce the drawbacks of those mobile applications, we conducted an exploratory study to investigate the public's perceptions toward crime information shared by the crowds and to identify the factors that motivate people and communities to participate in crowdsourcing of crime information. A part of the study findings have been reported in [17], which reveals that the survey respondents perceived the crime rate in the country as have been increasing and that crime information is often shared on social media, mobile messaging applications, mobile applications and online newspapers. Nevertheless, most respondents do not show high confidence and trust levels with the crime related information shared in these technologies particularly from mobile messaging application. Therefore, this paper focuses at presenting the results and findings of the second objective of the study, which is to identify the factors motivating people and communities in reporting and sharing crime-related information using crowdsourcing platforms particularly through mobile applications such as mentioned earlier.

In the remainder of this paper, Section 2 presents review of relevant literature. Section 3 presents the methodology that was adopted in conducting the survey to identify the factors from the respondents. Section 4 discusses the results and findings of the survey, whilst Section 5 concludes this paper.

\section{Literature Review}

For quite sometime, crowdsourcing has been identified as the huge thing due to its promising potentials. Many crowdsourcing applications are proven to be very successful as they are able to gain overwhelming participation from the crowd such as OpenStreetMap and Waze, just to name a few of many successful popular projects. The term 'crowdsourcing' was initially coined by Howe in [18]. He was inspired by Surowiecki in [19] who through an extensive research discovered that "under the right circumstances, groups are remarkably intelligent, and are often smarter than the smartest people in them", which is also termed as the "wisdom of crowds". Crowdsourcing is a model of a distributed problem solving and production process that through an open call, outsource tasks to an undefined, large group of people or community. There are three categories of collaborators of crowdsourcing approaches: 1) providers - also known as workers or individuals forming the crowd, 2) requesters - individuals or organizations requesting or benefitting from the crowd, and 3) platforms - mobile or web applications that link providers with requesters. According to Gebert [20], there are several approaches of crowdsourcing based on the aspects of level of payment, behaviour of competition and selection of strategies. The three crowdsourcing approaches are known as paid crowdsourcing, unpaid crowdsourcing, and competitive crowdsourcing. Table 1 summaries the brief descriptions and examples of these crowdsourcing approaches.

Table 1: Approaches of crowdsourcing [21]

\begin{tabular}{|c|c|c|c|}
\hline Approach & Description & Example & References \\
\hline $\begin{array}{c}\text { Unpaid } \\
\text { crowdsourcing }\end{array}$ & $\begin{array}{c}\text { The act of outsourcing } \\
\text { unpaid work where } \\
\text { Internet users contribute } \\
\text { such as idea, informa- } \\
\text { tion, knowledge or arti- } \\
\text { cles to an online com- }\end{array}$ & Waze & Open Signal \\
{$[23]$} \\
\end{tabular}

\begin{tabular}{|c|c|c|c|}
\hline & $\begin{array}{l}\text { munity platform for free } \\
\text { of charge. } \\
\text { The is the most common } \\
\text { forms of crowdsourcing } \\
\text { type. }\end{array}$ & Wikipedia & \\
\hline $\begin{array}{l}\text { Paid crowd- } \\
\text { sourcing }\end{array}$ & $\begin{array}{l}\text { The act of outsourcing } \\
\text { all kinds of paid work to } \\
\text { a large crowd using } \\
\text { crowdsourcing plat- } \\
\text { forms, which allows the } \\
\text { platforms' users to de- } \\
\text { fine, submit, coordinate, } \\
\text { accept, and pay for the } \\
\text { work done. }\end{array}$ & $\begin{array}{c}\text { Amazon } \\
\text { Mechanical } \\
\text { Turk } \\
\text { Freelancer } \\
\text { ClickWorker }\end{array}$ & $\begin{array}{l}{[24]} \\
{[25]}\end{array}$ \\
\hline $\begin{array}{l}\text { Competitive } \\
\text { crowdsourcing }\end{array}$ & $\begin{array}{l}\text { The act of crowdsourc- } \\
\text { ing that provide all kind } \\
\text { of open call to the regis- } \\
\text { tered members of online } \\
\text { crowdsourcing platforms } \\
\text { where people are always } \\
\text { free to become a member } \\
\text { of these platforms. }\end{array}$ & $\begin{array}{c}\text { InnoCentive } \\
\text { Spigit } \\
\text { Idea Con- } \\
\text { nection }\end{array}$ & $\begin{array}{l}{[26]} \\
{[27]}\end{array}$ \\
\hline
\end{tabular}

The success of online crowdsourcing platforms (regardless of the type of approach) is mostly influenced by the participation of the crowdsourcing providers. Generally, the motivation factors can be categorized as intrinsic and extrinsic motivations [28]. Intrinsic motivation refers to behaviour that is driven by internal reward such as hobby, enjoyment, interest and altruism [29]. In contrast extrinsic motivation involves engaging in behaviour to earn external rewards or avoid punishment such as monetary benefits, career, prize, recognition, reputation, status, peer pressure, fame and community identification. In identifying the motivation factors for participation in crowdsourcing platforms, we reviewed two widely known models: 1) “Model for Worker's Motivation in Crowdsourcing" [30], and 2) "Model of Text Correctors' Motivation in Crowdsourcing" [31]. Both models generally categorize the motivation factors to intrinsic and extrinsic motivation categories too. The "Model for Worker's Motivation in Crowdsourcing" focuses on motivation of providers in paid crowdsourcing platforms such as Amazon Mechanical Turk and structures the factors into five motivation categories: 1) engagement based motivation, 2) community based motivation, 3) immediate payoffs, 4) delayed payoffs, and 5) social Motivation. While the factors in the Model of Text Correctors' Motivation in Crowdsourcing are: 1) egoism-based motivations 2) community based motivations, 3) enjoyment based motivation and 4) social motivation, which is non-monetary rewards such as recognition and rewards are the secondary factor of users' participation.

Several other related models were also reviewed in this study including Motivational determinants [32], Motivational Affordances Theory [33] and Motivation factor of co-creation [34]. Based on the review of these models, several motivation factors were identified within the two general categories intrinsic and extrinsic motivations. The intrinsic factors include 1) altruism, 2) interest in topic, 3) nature of problem, 4) enjoyment, 5) learning, and 6) challenge. While the extrinsic factors are: 1) skill variety, 2) monetary reward, 3) recognition, 4) networking, 5) appreciation, 6) social contact, 7) reciprocity, and 8) self-efficacy. The definitions given by the online dictionaries: Cambridge Dictionary [35], Merriam Webster Dictionary [36] and Oxford Dictionary [37] of each of the intrinsic motivation factors are provided in Table 2, while definitions of the extrinsic motivation factors given by the Cambridge Dictionary [35], and Oxford Dictionary [37] are provided in Table 3.

Table 2: Definition of the intrinsic motivation factors

\begin{tabular}{|c|c|}
\hline Factor & Definition \\
\hline Altruism & $\begin{array}{c}\text { The attitude of caring about others and doing acts } \\
\text { that help them although you do not get anything by } \\
\text { doing those acts. }\end{array}$ \\
\hline Interest in topic & $\begin{array}{c}\text { The feeling of wanting to give your attention to } \\
\text { something or of wanting to be involved with and to }\end{array}$ \\
\hline
\end{tabular}




\begin{tabular}{|c|c|}
\hline Nature of problem & $\begin{array}{c}\text { discover more about something. } \\
\text { Nature of a situation, individual, or object that re- } \\
\text { quire consideration and requirements. }\end{array}$ \\
\hline Enjoyment & $\begin{array}{c}\text { The state or process of taking pleasure in something } \\
\text { and the action of possessing and benefiting from } \\
\text { something. }\end{array}$ \\
\hline Learning & The act or experience of one that learns. \\
\hline Challenge & $\begin{array}{c}\text { A dispute or confrontation or provocation to decide } \\
\text { who is superior in terms of capability or power. }\end{array}$ \\
\hline
\end{tabular}

Table 3: Descriptions of extrinsic motivation factors

\begin{tabular}{|c|c|}
\hline Factor & Definition \\
\hline Skill variety & Range of abilities needed to perform a specific job. \\
\hline Monetary reward & $\begin{array}{c}\text { The feeling of wanting to give your attention to } \\
\text { something or of wanting to be involved with and to } \\
\text { discover more about something. }\end{array}$ \\
\hline Recognition & $\begin{array}{c}\text { Identification of someone or something or person } \\
\text { from previous encounters or knowledge. }\end{array}$ \\
\hline Appreciation & $\begin{array}{c}\text { Social activity to interact with others with similar } \\
\text { interest. }\end{array}$ \\
\hline Social contact & $\begin{array}{c}\text { An unofficial agreement shared by everyone in a } \\
\text { society in which they give up some freedom for } \\
\text { security. }\end{array}$ \\
\hline Reciprocity & $\begin{array}{c}\text { Behaviours in which two people or groups of peo- } \\
\text { ple give each other help and advantages. }\end{array}$ \\
\hline Self-efficacy & $\begin{array}{c}\text { A person's belief that they can be successful when } \\
\text { carrying out a particular task. }\end{array}$ \\
\hline
\end{tabular}

\section{Methodology}

Questionnaire was chosen as the instrument of the survey conducted to investigate the pattern of the public's perceptions towards crowdsourced crime related information and crowdsourcing platforms for sharing crime incidents information (as reported in [17]) and to identify the factors that motivate people and communities to participate in crowdsourcing of crime information (to be explained in this paper). In order to capture the required information to meet the two main objectives of the survey, the questionnaire was constructed with three sections: Section A, Section B, and Section C. Section A using nine questions (Q1-Q9) requested the respondents for the background and profile information. The next eight questions (Q10-Q17) in Section B asked for perceived crime related information including types of crimes reported in the neighbourhood area during the last twelve months, level of crime and level of police protection in the community, frequency of coming across with shared crime-related information in relevant technologies as well as the level of confidence and trust on the shared crime information. The remaining five questions (Q18-Q22) in Section $C$ requested the respondents, who have experience in sharing crime information using the mentioned technologies, to identify motivation and demotivation factors for their participation. As discussed in Section 2, motivation factors can be divided into two categories: intrinsic motivation and extrinsic motivation. Each factor has at least one or more questions regarding user' motivation and demotivation factors to participate in crowdsourced crime reporting and sharing, and geo-tagging of media content. In question Q20, there are 22 statements representing user' motivation factors. About 12 statements representing intrinsic motivation are altruism (4), interest in topic (2), nature of problem (1), enjoyment (2), learning (1) and challenge (1). Another 10 statements representing extrinsic motivation are recognition (3), appreciation (1), social contact (2), reciprocity (2) and self-efficacy (2). In question Q21, there are 8 statements representing user' demotivation factors. The statements to representing intrinsic demotivation are altruism (2), interest in topic (1), nature of problem (1), learning (1) and challenge (1). Another 2 statements representing extrinsic demotivation are recognition (1) and reward (1). However, only results of motivation factors are discussed in this paper. The last question Q22 is an open-ended to enable respondents to share their general suggestions and comments.

The questions in Section B and C use the four point Likert scale data such as strongly agree, agree, disagree and strongly disagree. During the results analysis, these data were then collapsed and dichotomised to either 'supportive' or 'critical' responses, which is similar to the way results are analyzed in [38], and [39]. Collapsing and dichotomising the responses this way not only ease interpretations but also ease analysis of data. Moreover, as argued by Beecham and colleagues [38], "... collapsing the data in this way is less subjective as a person's 'agree' may be another person's 'strongly agree",

To avoid responder bias, a pilot study was conducted to the constructed questionnaire. The pilot study involves five participants from the public, who were chosen based on convenience random sampling. The pilot study ran a test on each item in the questionnaire against four test points, which are similarly tested in [40] and [41]. The pilot test was conducted to assess level of understanding, level of knowledge, level of difficulty in responding, level of relevance to subject area, and level of time commitment required by the respondents to complete the questionnaire. The questionnaire was finalised based on the responses received from the participants of the pilot study.

\section{Results and Discussion}

The population of the respondents is hard to be determined as there is no clear basis to identify them. Therefore, the 194 participants of the survey were selected because of their convenient accessibility and proximity to the researchers. Approximately 158 respondents were obtained from the crowds in the shopping malls, food court, mosque, Universiti Tenaga Nasional, and International Islamic University College, which are located in Selangor and Putrajaya states in the country. Another 36 respondents participated on the Web survey. This survey was conducted in five-week period from $19^{\text {th }}$ October 2015 to $16^{\text {th }}$ November 2015 . The responses of the returned questionnaire were then verified to reach the final participation list. The verification process of the data provided was performed to ensure the internal validity of data provided by the respondents. A few additional responses were received after this date, however, they were excluded because the analysis had already commenced. Out of 194 responses received, only $139(72 \%)$ responses are complete and deemed valid for analysis. The other 55 responses were considered invalid mainly due to missing information particularly from Section B and C. The results are discussed in the following sub-sections

\subsection{Demographic of Respondents}

From the valid responses, majority of the respondents are female (60\% or 83 ) and they aged between $21-25$ years old (30.2\% or 42 ) and above 31 (30.9\% or 43$)$. Almost one third $(32.3 \%$ or 49$)$ of the respondents are students studying in the abovementioned university and university college, and another one-third of the respondents are working in government/GLC sector, while the remaining respondents are from the private sector and unemployed as shown in Table 4. Almost 30\% (43) of the respondents spent 13 hours per day on the Internet and another one-third (27.3\% or 38 ) of respondents spent 3-6 hours, while $22.3 \%$ or 31 respondents spent up to six hours or more. These figures are quite disturbing as the weekly total time that might be spent by these people are much more higher that the reported 27 hours and 36 minutes in 2014 of weekly Internet time spent by the young adults reported by The Telegraph [42] which is "almost tripling from 10 hours and 24 minutes each week in 2005". However, on another note, this might be encouraging to the crime prevention technologies research and development that utilize mobile applications in crime sharing and reporting. The top two preferred devices to connect to the Internet are smartphone and laptop. The results are similar with the Mobile Internet Statistic and Facts 2017 reported by the Hostingfacts.com 
that there is more mobile Internet users than desktop Internet users in the world and that there are 3.5 billion global mobile Internet users as at August 2017 [43].

Table 4: Distribution of employment status of respondents

\begin{tabular}{|c|c|c|}
\hline Employment status & Frequency & Percentage (\%) \\
\hline Self-employed & 15 & 10.8 \\
\hline Government/GLC & 41 & 29.5 \\
\hline Private sector & 34 & 24.5 \\
\hline Not employed & 49 & 32.3 \\
\hline
\end{tabular}

\subsection{Motivation Factors}

More than half of the respondents (54\% or 74) had participated in crowdsourced crime reporting and sharing activities within the past twelve months. These respondents were then requested to identify the factors that motivate them to participate in the crime sharing and reporting activities. Table A.1 in Appendix A lists the results of the responses received for six intrinsic motivation factors that include actions or behaviours driven by internal rewards as defined earlier: 1) altruism, 2) interest in topic, 3) nature of problem, 4) enjoyment, 5) learning, and 6) challenge. As can be seen in Table A.1, the top four intrinsic factors that motivate the respondents to participate in reporting and sharing crime information are nature of problem (91.9\%), altruism (91.9\%), learning (87.4), and interest in topic (78.4\%). Although both the nature of problem and altruism factors received the same total value of supportive response rates, more respondents (31\% or 23$)$ strongly agreed with the former factor as compared to the latter factor (14.9\% or 11$)$.

Table A.2 in Appendix A lists the results of the responses received for the six extrinsic motivation factors: 1) recognition, 2) networking, 3) appreciation, 4) social contact, 5) reciprocity, and 8) selfefficacy. As can be seen, apparently there is only one extrinsic factor that may influence the respondents to share and report crime information with the crowds, which is reciprocity when more than $70 \%$ of them agreed with the statement that they share crime related information using technologies such mobile application, instant messages etcetera to help reduce the crime rates. These findings suggest the top 5 factors that influence the participation in crime sharing are nature of problem, altruism, learning, interest in topic and reciprocity. Also, it can be concluded that the crowd are more influenced by the intrinsic factors rather than extrinsic factors to participate in the crime sharing and reporting activities as compared to the extrinsic rewards and intrinsic enjoyment factors that drive participation in crowdsourcing platform reported in [44]. Nevertheless, the top motivation factors discovered in this survey have some similarities with the three motivation factors (intrinsic, altruistic, and ideological) of a related survey conducted by Aitamurto [45], in the journalism domain, which is concluded as " $b y$ sharing information, the crowd wants to contribute to social change and mitigate power and knowledge asymmetries, thus empowering their peers and creating a more informed citizenry. Participants don't expect tangible rewards like money; instead, they want to contribute to a better society, and crowdsourced journalism becomes a medium for social change and grassroots advocacy."

Eleven respondents provided additional suggestions and comments to the study. However, only two notable comments are seriously taken into consideration: 1) "Crime information sharing is good but it must come from trusted sources" and 2) "... apps should connect directly to the enforcement without congestion and the apps should feel like you bring the police in your pocket." Based on the two comments, we then provide the police validation function as part of the mobile application developed in the remaining of the research work, which is detailed in [21].

\section{Conclusion}

This paper presents the results of a survey conducted to identify the factors that motivate people and communities to participate in crowdsourcing of crime information. The results from valid responses show that the respondents share crime information mainly to help reduce the crime rate (nature of problem factor), to contribute to the betterment of mankind and they like the idea of contributing to something of value to the world (altruism factor); to exchange ideas/knowledge on crime information with the crowdsourcing community and to obtain crime related information (learning factor); to share crime related information to others (interest in topic); and to alert others so they can be more cautious (reciprocity factor).

Findings from this survey have guided a research that develop a prototype of mobile application to demonstrate how the application can support neighbourhood crime watch activity by enabling community members to share crime incidents information and receive near real-time alert of crime incidents that occur within certain radius. To avoid sharing of false report, each of the shared crime information must be verified by the authority, which shall be considered in other similar work too. The mobile application has gone through two-level of validation involving the public and the police officers. Detailed explanation of the mobile application can be found in [21].

\section{Acknowledgement}

Special thanks go to our respondents of the survey conducted. The study was funded by Ministry of Higher Education (MOHE) under Fundamental Research Grant Scheme 20130122FRGS.

\section{References}

[1] Bendler, J., A. Ratku and D. Neumann (2014). "Crime Mapping through Geo-Spatial Social Media Activity." In: Proceedings of the 14th International Conferences of Information Systems.

[2] Hindelang, M. J., Gottfredson, M. R., \& Garofalo, J. (1978). Victims of personal crime: An empirical foundation for a theory of personal victimization. Cambridge, MA: Ballinger.

[3] Cohen LE. Felson. M.(1979). Social change and crime rate trends A routine activity approach. American Sociological Review. 1979;44(4):588-608.

[4] Kadar, C., Te, Y.F., Rosés Brüngger, R. and Pletikosa Cvijikj, I., 2016, May. Digital Neighborhood Watch: To share or not to share? In Proceedings of the 2016 CHI Conference Extended Abstracts on Human Factors in Computing Systems (pp. 2148-2155). ACM.

[5] Ratcliffe, J. H. (2004). "Crime mapping and the training needs of law enforcement." European Journal on Criminal Policy and Research 10 (1), 65-83.).

[6] CrimeReports (2015). URL: https://www.crimereports.com/ (visited on $11 / 26 / 2015)$

[7] Crimemapping (2015). URL: http://www.crimemapping.com/ (visited on 11/26/2015).

[8] Eck, J., S. Chainey, J. Cameron, M. Leitner and R. Wilson (2005). Mapping crime: Understanding hotspots. USA: National Institute of Justice.

[9] Perry, W. L. (2013). Predictive policing: The role of crime forecasting in law enforcement operations. Rand Corporation.

[10] WikiCrimes (2015). URL: http://www.wikicrimes.org/ (visited on $11 / 26 / 2015)$.

[11] CrimePush (2015). URL: http://crimepush.com/ (visited on 11/26/2015).

[12] Blythe, M. A., P. C. Wright and A. F. Monk (2004). "Little brother: could and should wearable computing technologies be applied to reducing older people's fear of crime?" Personal and Ubiquitous Computing 8 (6), 402-415.

[13] Czeskis, A., I. Dermendjieva, H. Yapit, A. Borning, B. Friedman, B. Gill and T. Kohno (2010). "Parenting from the pocket: Value tensions and technical directions for secure and private parent-teen mobile safety." In: Proceedings of SOUPS. 
[14] Satchell, C. and M. Foth (2011). "Welcome to the jungle: HCI after dark." In: CHI'11 Extended Abstracts on Human Factors in Computing Systems (pp. 753-762). ACM.

[15] Blom, J., D. Viswanathan, M. Spasojevic, J. Go, K. Acharya and R. Ahonius (2010). "Fear and the city: role of mobile services in harnessing safety and security in urban use contexts." In: Proceedings of the SIGCHI Conference on Human Factors in Computing Systems (pp. 1841-1850). ACM.

[16] Ariffin, I., Solemon, I., and Bakar, WMLWA. "An evaluative study on mobile crowdsourcing applications for crime watch". In 2014 International Conference on Information Technology and Multimedia (ICIMU), pp. 335-340. IEEE, 2014.

[17] Bakar, WMLWA, and Solemon, B. "Exploring the public's perception towards crowdsourced crime reporting." In the 6th International Conference on Computing and Informatics 2017 (ICOCI2017).

[18] Howe, J. (2006). The rise of crowdsourcing. Wired magazine, 14(6), $1-4$.

[19] Surowiecki, J. (2004). The wisdom of crowds: Why the many are smarter than the few and how collective wisdom shapes business. Economies, Societies and Nations, 296.

[20] Gebert, M. (2014). Crowdsourcing and Risk-Management.

[21] Bakar, WMLWA. (2018). A Mobile Crowdsourcing Platform for Facilitating Community Crime Watch. Master Thesis. Universiti Tenaga Nasional.

[22] Kleemann, F., Voß, G. G., \& Rieder, K. (2008). Un (der) paid innovators: The commercial utiliza-tion of consumer work through crowdsourcing. Science, technology \& innovation studies, 4(1), PP $5-26$.

[23] Borromeo, R. M., \& Toyama, M. (2016). An investigation of unpaid crowdsourcing. Human-centric Computing and Information Sciences, 6(1), 11.

[24] Horton, J. J., \& Chilton, L. B. (2010). The labor economics of paid crowdsourcing. Proceedings of the 11th ACM Conference on Electronic Commerce.

[25] Frei, B. (2009). Paid crowdsourcing: Current state \& progress toward mainstream business use. Smartsheet White Paper.

[26] Schenk, E., \& Guittard, C. (2011). Towards a characterization of crowdsourcing practices. Journal of Innovation Economics \& Management(1), 93-107.

[27] Vukovic, M., \& Bartolini, C. (2010). Towards a research agenda for enterprise crowdsourcing. Paper presented at the International Symposium On Leveraging Applications of Formal Methods, Verification and Validation.

[28] Deci, E. L., \& Ryan, R. M. (1985). The general causality orientations scale: Self-determination in personality. Journal of research in personality, 19(2), 109-134.

[29] Hossain, M. (2012). Users' motivation to participate in online crowdsourcing platforms. Proceedings of the 2012 International Conference on Innovation Management and Technology Research (ICIMTR).

[30] Kaufmann, N., Schulze, T., \& Veit, D. (2011). More than fun and money. Worker Motivation in Crowdsourcing-A Study on Mechanical Turk. Paper presented at the AMCIS.

[31] lam, S. L., \& Campbell, J. (2012). Crowdsourcing motivations in a not-for-profit GLAM context: the Australian newspapers digitisation program. Paper presented at the ACIS 2012: Location, location, location: Proceedings of the 23rd Australasian Conference on Information Systems 2012.

[32] Send, H., Friesike, S., \& Zuch, A. N. (2014). Participation in OnLine Co-Creation: Assessment and Review of Motivations.

[33] Zhao, Y., \& Zhu, Q. (2012). A Conceptual Model for Participant's Motivation in Crowdsourcing Contest. Paper presented at the Eleventh Wuhan International Conference on E-business.

[34] Gourova, E., \& Toteva, K. (2011). Raising creativity and participation in innovation and knowledge management activities. Paper presented at the Concurrent Enterprising (ICE), 2011 17th International Conference on.

[35] Cambridge Dictionary. URL http://dictionary.cambridge.org. (visitied on 05/03/2015).

[36] Merriam Webster Dictionary. URL https://www.merriamwebster.com. (visited on 05/03/2015).

[37] Oxford Dictionary. URL https://en.oxforddictionaries.com. (visited on $05 / 03 / 2015$ ).

[38] Beecham, S., Hall, T., \& Rainer, A. (2003). Software process improvement problems in twelve software companies: An empirical analysis. Empirical software engineering, 8(1), 7-42.
[39] Solemon, B. (2012). Requirements Engineering Process Assessment and Improvement Approach for Malay-sian Software Industry (Doctoral dissertation, Universiti Teknologi Malaysia).

[40] Berry, M., \& Jeffery, R. (2000). An instrument for assessing software measurement programs. Empirical Software Engineering, 5(3), 183-200.

[41] Beecham, S., Hall, T., Britton, C., Cottee, M., \& Rainer, A. (2005). Using an expert panel to validate a requirements process improvement model. Journal of Systems and Software, 76(3), 251-275.

[42] The Telegrapgh.

\section{URL} http://www.telegraph.co.uk/finance/newsbysector/mediatechnology andtelecoms/digital-media/11597743/Teenagers-spend-27-hours-aweek-online-how-internet-use-has-ballooned-in-the-lastdecade.html. (visited on 06/02/2016).

[43] HostingFacts.com. URL https://hostingfacts.com/internet-factsstats-2016/. (visited on 02/20/2017).

[44] Ahmad, R., Mahmod, M., Chit, S. C., Na'in, N., Habbal, A., \& Wiwied, V. (2017). More Than Money Matters: Examining Motivational Factors for Participating in Crowdsourcing Platform. Advanced Science Letters, 23(5), 4310-4313.

[45] Aitamurto, T. (2015). Motivation factors in crowdsourced journalism: Social impact, social change, and peer learning. URL http://ijoc.org/index.php/ijoc/article/download/3481/1502. (visited on $08 / 08 / 2016$ ). 


\section{Appendix A: Influencing Factors}

Table 3: Results of Intrinsic Influencing Factors

\begin{tabular}{|c|c|c|c|c|c|}
\hline Factor & $\begin{array}{c}\text { Statements } \\
\text { I share crime related information using the abovemen- } \\
\text { tioned technologies because... }\end{array}$ & $\mathrm{N}$ & $\begin{array}{c}\text { Critical Re- } \\
\text { sponses }\end{array}$ & $\begin{array}{l}\text { Supportive Re- } \\
\text { sponses }\end{array}$ & $\%$ \\
\hline Nature of problem & $\begin{array}{l}\text { I share crime related information using the abovemen- } \\
\text { tioned technologies to alert others so they can be more } \\
\text { cautious. }\end{array}$ & 74 & 6 & 68 & 91.9 \\
\hline Altruism & I want to contribute to the betterment of mankind. & 74 & 6 & 68 & 91.9 \\
\hline Learning & $\begin{array}{l}\text { I learn something due to the sharing of crime information } \\
\text { with community members. }\end{array}$ & 72 & 9 & 61 & 87.4 \\
\hline Interest in topic & $\begin{array}{c}\text { I am interested in sharing crime related information to } \\
\text { others. }\end{array}$ & 74 & 16 & 58 & 78.4 \\
\hline Challenge & $\begin{array}{l}\text { I share crime related information to be superior to other } \\
\text { community members. }\end{array}$ & 74 & 40 & 34 & 45.8 \\
\hline Enjoyment & $\begin{array}{c}\text { I enjoy identifying other people's crime related photos } \\
\text { and having them classified. }\end{array}$ & 74 & 44 & 40.6 & 40.6 \\
\hline
\end{tabular}

Table 4: Results of Extrinsic Influencing Factors

\begin{tabular}{|c|c|c|c|c|c|}
\hline Factor & $\begin{array}{c}\text { Statements } \\
\begin{array}{c}\text { I share crime related information using the abovemen- } \\
\text { tioned technologies because... }\end{array}\end{array}$ & $\mathrm{N}$ & $\begin{array}{l}\text { Critical Re- } \\
\text { sponses }\end{array}$ & $\begin{array}{l}\text { Supportive Re- } \\
\text { sponses }\end{array}$ & $\%$ \\
\hline Reciprocity & $\begin{array}{l}\text { I share crime related information using the abovemen- } \\
\text { tioned technologies to help reduce the crime rate. }\end{array}$ & 73 & 18 & 55 & 75.4 \\
\hline Networking & $\begin{array}{l}\text { I share crime related information using the abovemen- } \\
\text { tioned technologies to establish contact with regard to } \\
\text { crime prevention activities or parties. }\end{array}$ & 73 & 38 & 35 & 47.9 \\
\hline Social contact & $\begin{array}{l}\text { I share crime related information using the abovemen- } \\
\text { tioned technologies to make new friends from the crowd- } \\
\text { sourcing community. }\end{array}$ & 73 & 49 & 24 & 32.9 \\
\hline Self-eficacy & $\begin{array}{l}\text { I share crime related information using the abovemen- } \\
\text { tioned technologies because it gives me a feeling of } \\
\text { competence. }\end{array}$ & 73 & 49 & 24 & 32.9 \\
\hline Appreciation & $\begin{array}{l}\text { I share crime related information to gain appreciation } \\
\text { from community members. }\end{array}$ & 73 & 49 & 24 & 32.8 \\
\hline Recognition & $\begin{array}{l}\text { I share crime related information to gain recognition } \\
\text { from community members. }\end{array}$ & 74 & 48 & 26 & 32.4 \\
\hline
\end{tabular}

